\title{
HYPEROSTOSIS FRONTALIS INTERNA IN A PATIENT WITH AXIAL SPONDYLOARTHRITIS - A CASE REPORT
}

João Pedro de Oliveira Aucélio, , , Aline Rizzo Borges ${ }^{1}$, Ana Beatriz Caetano Vieira2, Beatriz Carneiro Passos ${ }^{1}$, Beatriz Pires Paes $^{1}$, Beatriz Toledo Mendes ${ }^{1}$, Bruna de Paula Gonçalves Sousa Lyra ${ }^{1}$, Gabriela Brill Ney ${ }^{3}$, Gabriela Furlan Ribeiro Barbosa Netto ${ }^{2}$, Gustavo Araújo do Nascimento Santos ${ }^{1}$, Heloísa Lima Heller ${ }^{1}$, Letícia Laranjeiras Amaral ${ }^{1}$, Luís Otávio Amarantes Franco ${ }^{1}$, Marcos Igor Albanaz Vargas ${ }^{1}$, Maria Luiza Pimentel de Oliveira ${ }^{1}$, Maria Teresa Aires Cabral Dias ${ }^{2}$, Mariah Vicari Bolognani ${ }^{3}$, Matheus Macêdo da Silva ${ }^{1}$, Maurício Silva de Jesus ${ }^{1}$, Mirella Bastos Sales ${ }^{1}$, Natália Vargas do Nascimento ${ }^{2}$, Paulo Ricardo Guimarães Rocha Storni ${ }^{4}$, Rebeca Naoum Lorga ${ }^{1}$, Tamires Martinelli de Oliveira Ferraz ${ }^{1}$, Viviane Cristina Uliana Peterle ${ }^{1}$, Ana Paula Gomides ${ }^{1}$

1.Centro Universitário de Brasília, Brasília (DF), Brazil. 2.Universidade Católica de Brasília, Brasília (DF), Brazil. 3.Faculdades Integradas da União Educacional do Planalto Central, Brasília (DF), Brazil. 4.Centro Universitário Euro-Americano, Brasília (DF), Brazil.

*Corresponding author: jp.aucelio@gmail.com

\section{BACKGROUND}

Hyperostosis frontalis interna is defined by an abnormal thickening of the frontal bone. Its etiology remains uncertain, but occurs more commonly in postmenopausal women. It can develop isolated or associated with a syndrome with symptoms such as severe headache, dizziness, vertigo, seizures, visual, gait and balance disorders. The diagnosis is made mainly by conventional radiographs.

\section{CASE REPORT}

A 35-year-old female patient attended for rheumatological evaluation complaining of the following symptoms started about one year ago: inflammatory lower back pain, persistent pain in the buttocks and elbows, short-term morning stiffness and frequent headache. Physical examination showed movement limitation because of pain in the lower back, pain during elbow palpation and sacroiliac region and positive signs for bilateral sacroilitis (Patrick's FABER test). Complementary clinical examination showed high CRP, negative HLAB27 and nuclear magnetic resonance imaging indicating bilateral sacroilitis. Scintigraphy revealed sharp contrast in sacroiliac and cranial topography and elbow ultrasound appointing bilateral chronic enthesitis. The patient was diagnosed with spondyloarthritis and started the treatment with nonsteroidal anti-inflammatory drugs (NSAIDs), evolving with improvement of the symptoms after 30 days. Due to skullcap scintigraphy alterations, a skull radiography was requested (Fig. 1) and hyperostosis frontalis interna was diagnosed.
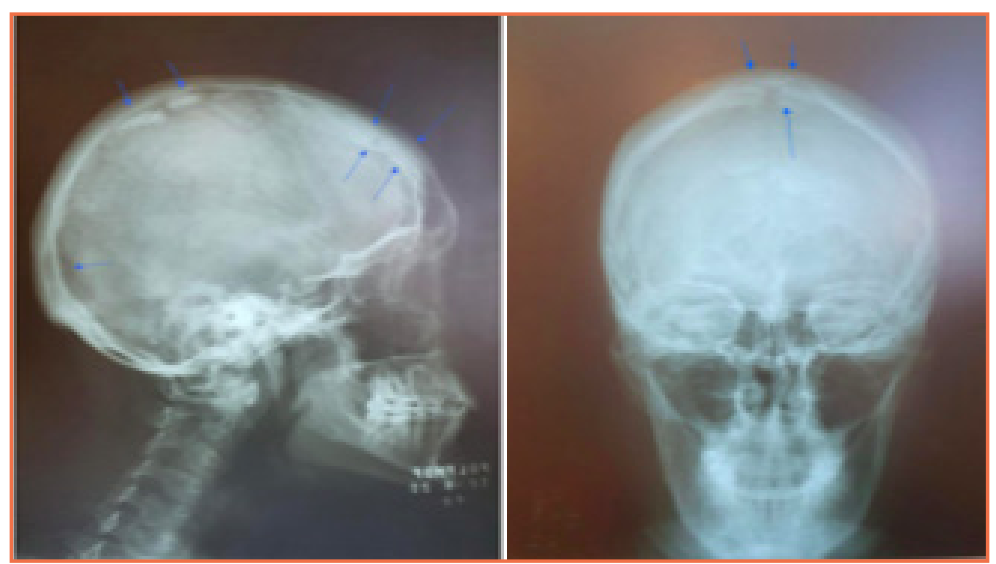

Figure 1. Thickening and irregular, almost nodular sclerosis, more evident in the frontal, but also in the parietal, compatible with internal frontal hyperostosis.

\section{CONCLUSION}

Hyperostosis frontalis interna generally is associated with several diseases, mainly epilepsy, diverse metabolic disorders and Alzheimer's disease. In the case presented, the diagnosis was simultaneous with a picture of axial spondyloarthritis, a rare association and not yet described in the literature. 